\section{idanoturn}

Jurnal Kajian Manajemen Dakwah
Volume 3, Nomor 3, Oktober 2021

P-ISSN: 2654-4709

E-ISSN: 2654-4938

DOI: 10.24014/idarotuna.v3i3.16440

\title{
Strategi Komunikasi Dakwah bil Qalam Komunitas Revowriter di Media Digital
}

\author{
Rusyda Fauzana $^{1}$ \\ ${ }^{1}$ Universitas Islam Negeri Sultan Syarif Kasim Riau \\ Email: rusyda@uin-suska.ac.id
}

\begin{abstract}
Technology advancement nowadays has enhanced dakwah becomes easier. Several dakwah methods have been conducted by using internet. Each dakwah method has respective uniqueness, as well as the dakwah bil qalam method which focuses on writing. Revowriter is a writing community carries dakwah by online media in disseminating their content. This research aims to delve the strategy of dakwah bil qalam by Revowriter Community on online media. This research used qualitative approach with case study research design which digs purposeful information from the founder and members of the community related to the research objective. The theory used in this research is media ecology by McLuhan which asserted that media is the environment for society that influences their life. The result of this research shows that Revowriter community in disseminating dakwah through writing has used the characteristic of new media namely convergence. The global new media has made it easier to spread dakwah message through various online media platform not limited by space and time. Online media accommodates the archive of dakwah message through writing which can be accessed and shared anytime.
\end{abstract}

Keywords: Dakwah bil qalam, Writing community, Digital media

Abstrak: Kemajuan teknologi saat ini telah membawa memudahkan penyebaran dakwah. Berbagai metode dakwah dijalankan dengan memanfaatkan media internet. Tiap metode dakwah memiliki keunikannya sendiri, termasuk metode dakwah bil qalam yang berfokus pada dakwah melalui tulisan. Revowriter adalah komunitas menulis untuk tujuan dakwah yang memanfaatkan media online dalam penyebaran dakwahnya. Penelitian ini bertujuan untuk menggali strategi dakwah bil qalam Komunitas Revowriter di media online. Penelitian ini menggunakan pendekatan kualitatif dengan desain penelitian studi kasus yang menggali informasi dari pendiri dan anggota Komunitas Revowriter yang dapat membagi informasi sesuai dengan tujuan penelitian. Teori yang digunakan dalam penelitian ini adalah teori Ekologi Media yang digagas oleh McLuhan bahwa media sebagai lingkungan hidup yang mempengaruhi kehidupan manusia. Hasil penelitian menunjukkan bahwa Komunitas Revowriter dalam penyebaran dakwah lewat tulisan memanfaatkan karakteristik media baru yang terkonvergensi. Karakter media baru yang bersifat global telah memudahkan pesan dakwah tersampaikan ke dalam berbagai platform media online tanpa dibatasi ruang dan waktu. Media online mampu mengakomodasi pengarsipan pesan dakwah lewat tulisan dan dapat dibuka dan disebarkan kapanpun.

Kata kunci: Dakwah bil qalam, Komunitas menulis, Media digital

\section{Pendahuluan}

Aktivitas dakwah dalam Islam terus dijalankan dari masa ke masa. Ini adalah kewajiban yang diserukan oleh Allah bagi muslim sebagaimana yang dijelaskan dalam Al-Quran pada surah Ali Imran ayat 110 bahwa umat Islam adalah umat terbaik yang dilahirkan, yang menyeru berbuat yang makruf, mencegah perbuatan mungkar, dan mereka beriman pada Allah. Aktivitas 
dakwah ini ditujukan kepada muslim maupun yang nonmuslim (Abdullah, 2019; Al-Haddad, 2018). Aktivitas dakwah tidak hanya dilakukan oleh para ulama, mubalig,dan ustaz saja tapi juga organisasi keislaman, komunitas dakwah, bahkan dalam bentuk dakwah fardhiyah yaitu dakwah yang dilakukan secara individu (Ahmad, 2014). Setiap muslim harus bertanggung jawab atas semua kejadian yang ada di sekitarnya, mereka harus berusaha menegakkan kebenaran dan menghilangkan kebatilan di setiap waktu dan tempat sesuai dengan kemampuan dan keahliannya. Kewajiban dakwah dijelaskan di dalam hadits yang diriwayatkan oleh Imam Muslim yaitu seruan bagi setiap muslim untuk menyampaikan apa yang dibawa Rasulullah walaupun satu ayat (Abdullah, 2019; Al-Madkhali, 2006; Masyhur, 2014).

Dalam dakwah sangat penting memperhatikan strategi penyampaiannya agar dapat diterima dan tersampaikan dengan baik kepada obyek dakwah. Dakwah bil qalam atau dakwah melalui tulisan adalah metode komunikasi dakwah yang mengutamakan kemampuan menulis. Rasulullah pernah mencontohkan dakwah ini dengan mengirimkan surat berisi ajakan dakwah pada Islam kepada raja-raja di sekitar jazirah Arab (Abdullah, 2019).

Dalam beberapa penelitian, dakwah bil qalam cukup berkembang di Indonesia. Dakwah bil qalam adalah ciri dakwah intelektual yang dilakukan oleh tokoh-tokoh pejuang Islam dahulu di tanah air yaitu Syekh Nawawi al-Bantani dan Sultan Agung. Mereka menyebarkan dakwah lewat metode dakwah bil qalam dengan menghasilkan karya tulis berupa buku-buku. Aktivitas dakwah tokoh-tokoh ini disebut juga dengan jihad intelektual melawan penjajah pada masa itu (Adeni \& Hasanah, 2020; Jalaludin et al., 2021).

Di masa orde baru setelah Indonesia merdeka, dakwah bil qalam masih tetap berkembang dengan terbitnya beberapa majalah dan surat kabar yang kental dengan ciri dakwah Islam seperti majalah Sabili, Ummi, dan Republika. Media cetak ini menyebarkan dakwah lewat tulisan di tengah-tengah umat. Gerakan dakwah lewat tulisan di media cetak berkembang karena di masa itu dakwah melalui lisan di masjid-masid dan forum-forum seminar dilarang oleh pemerintah. Oleh karena itu, para aktivitas Islam mulai mengambil cara yang dianggap lebih aman dalam menyampaikan pesan dakwah yaitu lewat tulisan (Al Isra, 2019).

Hingga masuk ke era reformasi dan setelahnya, dakwah bil qalam adalah pilihan yang cukup populer dan berpengaruh. Pada masa ini banyak terbit buku-buku bermuatan dakwah Islam yang ditulis oleh para penulis muslim dan para dai seperti Salim Al Fillah, Tasaro G.K, Oki Setiana Dewi, Helvy Tiana Rosa, Asma Nadia, dll. Masuk ke era digital sekarang, metode dakwah lewat tulisan masih digunakan dengan cara kreatif untuk menyampaikan nilai-nilai Islam yang disesuaikan dengan platform yang ada. Dalam penelitiannya, Mupida \& Shalihati memunculkan istilah komodifikasi Islam dari spiritual ke ekonomi karena konten-konten dakwah di buku yang ditulis oleh Salim Al-Fillah menjadi bisnis literasi dakwah. Ini disebabkan oleh tingginya minat akan buku-buku Islam yang dipengaruhi oleh latar belakang penulisnya yang memiliki otoritas dalam menyampaikan pesan dakwah dengan keberadaannya sebagai dai (Mupida \& Shalihati, 2019).

Kemampuan literasi yang baik dan gaya komunikasi yang menyesuaikan dengan karakter obyek dakwah adalah kunci dalam mengajak orang memahami Islam melalui tulisan. 
Keunggulan dakwah bil qalam adalah mad'u atau obyek dakwah akan mendapatkan pemahaman yang runut dan detail, yang tidak didapatkan secara utuh dalam dakwah bil lisan (Fitria \& Aditia, 2019).

Kemajuan teknologi komunikasi yang semakin canggih telah mengubah cara berkomunikasi masyarakat, tidak terkecuali dalam penyampaian pesan dakwah. Merujuk kepada penelitian yang dilakukan oleh Briandana dkk yang menjelaskan bahwa munculnya platform media sosial telah memudahkan aktivitas dakwah. Ini karena akun media sosial yang berfungsi untuk menjalin atau mempererat hubungan pertemanan dan keluarga dengan berbagi berbagi informasi, ternyata memberikan pengaruh yang baik dalam penyebaran konten dakwah. (Briandana et al., 2020). Ini juga diperkuat oleh beberapa penelitian bahwa adanya media sosial telah memudahkan para dai dan pengemban dakwah dalam menyebarkan dakwah di berbagai kalangan, terutama kalangan anak muda yang aktif menggunakan media sosial. Media sosial membantu mereka dalam membangun identitas personal di hadapan obyek dakwah, membuka akses dakwah, dan pencarian informasi tentang Islam (Ali et al., 2021; Latepo et al., 2021; Omar et al., 2015)

Internet sebagai media baru telah menjadi teknologi yang sangat berpengaruh bagi hidup manusia saat ini. Semua aktivitas komunikasi dan pencarian informasi sangat bergantung pada internet atau media online. Inilah yang diungkapkan Marshall McLuhan dalam teori Ekologi Media bahwa masyarakat sangat bergantung kepada teknologi yang menjadi media bagi aktivitas manusia. Selanjutnya tatanan sosial akan dipengaruhi oleh kemampuan masyarakat dalam menggunakan teknologi tersebut. McLuhan berpandangan bahwa media adalah lingkungan yang membentuk budaya dan mempengaruhi kehidupan manusia (West \& Turner, 2018). Selain itu, konsep global village yang diinisiasi oleh McLuhan menggambarkan bagaimana media mengalami konvergensi seperti saat ini menjadi satu media yaitu media digital. Media ini dapat diakses oleh siapa pun tanpa batas ruang dan waktu hingga muncul istilah netizen yaitu sebutan untuk warga di media online. Mereka bisa berinteraksi dengan siapa pun serta berbagi dan mendiskusikan apa pun tanpa sekat atau batas. Dalam konvergensi media, seluruh karakter media yang ada pada media tradisional dapat disatukan menjadi satu media atau disebut multimedia. Media digital lebih unggul karena bisa membawa pengaruh ke seluruh dunia tanpa batas atau bersifat global (Littlejohn \& Foss, 2009).

Jika sebelumnya masyarakat mengakses media cetak untuk membaca berita, informasi, ataupun artikel opini, maka saat ini dengan adanya internet, budaya membaca dari media cetak berangsur beralih ke media online. Apalagi media online memiliki banyak kelebihan yang tidak didapatkan di media cetak seperti dalam hal penyimpanan data yang lebih aman, data bisa diperbanyak dengan mudah, serta bisa dikonversikan ke berbagai aplikasi. Seperti inilah media digital membentuk budaya masyarakat dalam mengakses informasi. Karakter media seperti ini dimanfaatkan oleh komunitas Revowriter dalam komunikasi dakwah mereka lewat tulisan. Dengan ulasan fenomena, kajian penelitian terdahulu, serta landasan teoretis seperti di atas, penelitian ini bertujuan untuk menggali strategi komunitas Revowriter dalam menggunakan media digital untuk penyebaran konten dakwah mereka. 


\section{Metode}

Penelitian ini menerapkan prosedur penelitian kualitatif. Penelitian kualitatif terdiri atas sekumpulan penafsiran, praktik material yang membuat dunia terlihat dengan jelas. Praktik ini mentrasformasikan dunia menjadi serangkaian representasi, catatan lapangan, wawancara, percakapan, foto, rekaman, dan memo. (Denzin \& Lincoln, 2018). Ini sejalan dengan pendapat Creswell bahwa penelitian kualitatif adalah pendekatan yang mengeksplorasi dan memahami makna individu atau kelompok yang berhubungan dengan masalah sosial. Proses penelitiannya dilakukan dengan membuat pertanyaan dan prosedur, mengumpulkan data dari partisipan, kemudian data dianalisis dari hal yang khusus ke yang umum (Creswell, 2014). Dalam penelitian ini dilakukan wawancara kepada informan lalu diinterpretasikan dengan mengaitkan fenomena dan hasil wawancara tersebut.

Informan dipilih berdasarkan tenik purposeful sampling di mana peneliti memilih orangorang atau tempat untuk diteliti karena dapat memberikan pemahaman tentang masalah dan fenomena sentral penelitian yang sesuai dengan tujuan penelitian (Creswell \& Poth, 2016). Informan penelitian ini adalah pendiri Komunitas Revowriter dan beberapa penulis yang dapat memberikan informasi tambahan terkait penelitian yang dilakukan. Sedangkan desain penelitian menggunakan studi kasus yaitu penelitian menggali tentang permasalahan yang sifatnya spesifik yang terjadi pada orang per orang, komunitas, dan peristiwa. Kasus yang digali adalah kasus yang sedang terjadi atau sifatnya kontemporer sehingga informasi tidak hilang atau luput dari perhatian. Dalam penelitian studi kasus akan didapatkan sudut pandang yang banyak dengan ulasan narasi yang luas dari berbagai latar belakang informan yang tidak homogen (Creswell \& Poth, 2016; Patton, 2015). Pada penelitian ini, sudut pandang tentang dakwah bil qalam di media digital akan didapatkan dari uraian pendiri Komunitas Revowriter sebagai penggerak dan pengarah aktivitas serta yang membangun visi dan strategi dakwah komunitas, kemudian dari sudut padang para anggota komunitas yang sudah malang melintang menulis dan mengirimkan tulisan mereka ke berbagai media online.

Penelitian ini tidak hanya dilakukan dengan wawancara, tetapi juga mengumpulkan dokumen-dokumen digital seperti karya tulisan komunitas Revowriter di berbagai media, mengamati media sosial Komunitas Revowriter yang di sana ditampilkan agenda acara internal mereka dan untuk umum, serta interaksi anggota Revowriter yang saling berbagi informasi dan dukungan dalam menulis serta menginspirasi satu sama lain. Data penelitian yang terkumpul dianalisis dengan mengikuti tahapan kondensasi data, penyajian data, dan penarikan kesimpulan (Miles \& Huberman, 2014).

\section{Hasil dan Pembahasan}

Komunitas Revowriter adalah komunitas menulis yang didirikan pada Juli 2017 oleh Asri Supatmiati, seorang jurnalis, penulis, dan trainer. Komunitas ini adalah pengembangan dari grup menulis yang didirikan Ibu Asri tahun 2012, namun tidak terkelola dengan baik karena belum terbentuk struktur di grup tersebut. Setelah brand Revowriter digagas tahun 2017 dan dibukanya 
kelas menulis, anggota grup menulis sebelumnya ikut bergabung di Komunitas Revowriter. Latar belakang munculnya komunitas ini tidak lepas dari pengaruh perkembangan media digital. Beliau melihat dengan tersedianya media internet yang sifatnya terbuka dan dapat digunakan oleh siapapun, maka tuntutan dakwah sudah harus masuk ke media digital untuk dijadikan pangggung dakwah dalam menyampaikan pesan-pesan kebaikan. Beliau mengamati banyak orang menggunakan media sosial hanya untuk berbagi hal-hal yang sifatnya pribadi serta menjalin pertemanan yang terkadang tidak memiliki target dan tujuan yang jelas. Bahkan sering kali konten yang disebarkan tidak terlalu bermanfaat bagi yang melihatnya. Padahal, media sosial dapat dimafaatkan untuk hal yang lebih berpengaruh karena memiliki jaringan yang luas dan dapat diakses oleh siapa pun. Maka dari itu, Ibu Asri berpikir seharusnya media sosial dapat dimanfaatkan untuk tujuan dakwah dan menyebarkan hal yang bermanfaat.

\section{Gambar 1. Poster Pendaftaran Kelas Revowriter}
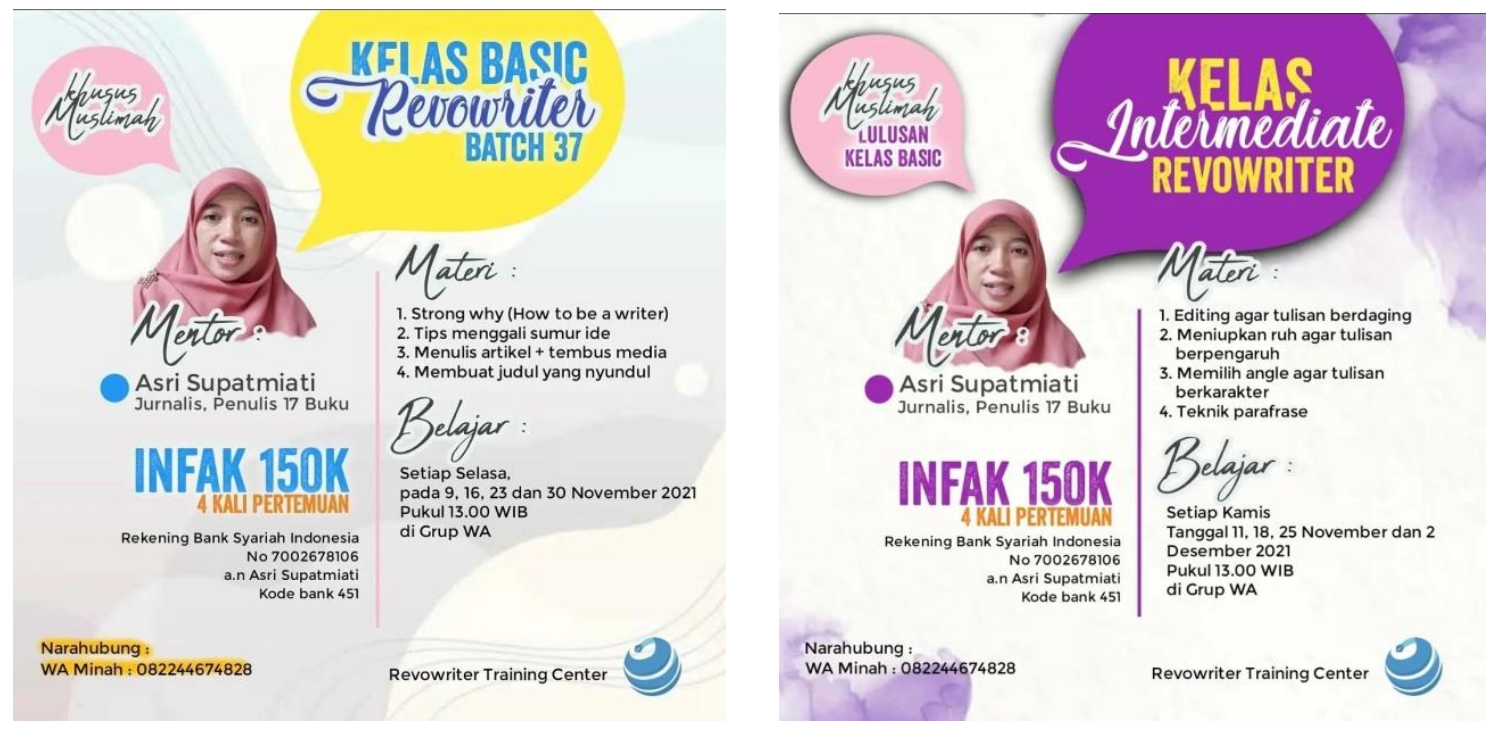

Sumber: Instagram @ revowiter

Komunitas Revowriter melatih penulis pemula untuk menulis tulisan yang membawa konten dakwah ke tengah masyarakat. Ibu Asri mengatakan bahwa latar belakang menjadikan komunitas Revowriter sebagai komunitas menulis untuk tujuan dakwah di media online, selain karena pesatnya perkembangan media digital, juga karena beliau merasa prihatin dengan meningkatnya tekanan politik yang represif pada kegiatan dakwah di tahun 2017 tersebut, seperti maraknya kasus pembubaran pengajian di masyarakat. Melihat kondisi itu, Ibu Asri berinisiatif untuk mengajak orang-orang khususnya muslimah, yang mempunyai passion menulis, untuk ikut bergabung dalam komunitas Revowriter. Aktivitasnya utamanya adalah melakukan dakwah lewat tulisan dan menyebarkan pemahaman Islam di media online. Ajakan ini mendapat sambutan dengan bergabungnya sebanyak 400 orang ke dalam komunitas. Anggota komunitas terhubung dalam aplikasi Whatsapp. Motivasi yang ditumbuhkan dalam diri anggota komunitas ini adalah motivasi ruhiyah. Dengan motivasi ruhiyah maka seseorang akan tergerak berdakwah 
dengan alasan keimanan. Agar semangat anggota komunitas tetap istiqamah dalam menulis, maka Ibu Asri membuat modul-modul kepenulisan. Hingga saat ini anggota Revowriter sudah mencapai 1500 orang yang terdiri dari muslimah dengan latar belakang beragam seperti mahasiswa, ibu rumah tangga, akademisi, pekerja, dan pengemban dakwah.

\section{Gambar 2. Ajakan rekrutmen Komunitas Revowriter}

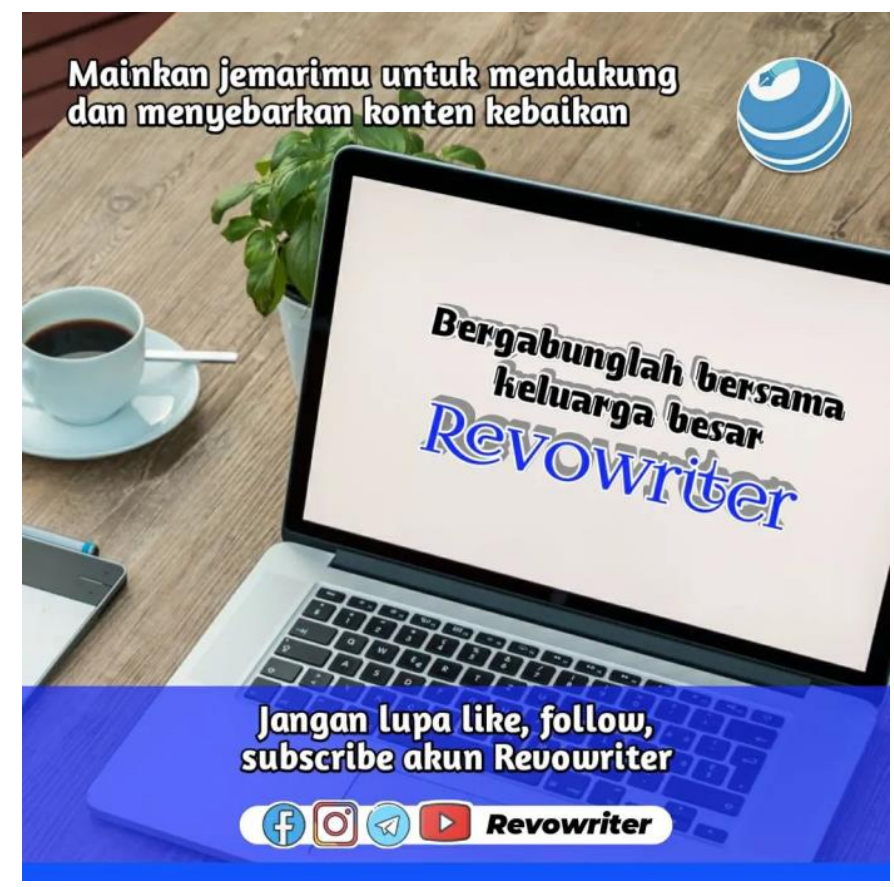

Sumber: Instragram @ revowriter

\section{Dakwah bil Qalam dan Upaya Peningkatan Minat Baca Umat}

Saat ini di tengah maraknya penggunaan media online untuk penyebaran dakwah, konten dakwah dengan penyampaian bil qalam memang terbilang lebih sedikit dibanding dakwah bil lisan seperti video. Ketika ditanyakan kepada pendiri komunitas mengapa memilih cara dakwah melalui tulisan, beliau mengatakan karena latar belakangnya yang seorang penulis dan jurnalis maka skill yang beliau adalah mengembangkan hal yang berkaitan dengan kepenulisan. Selain itu, alasan lain beliau adalah karena prihatin dengan minat baca masyarakat Indonesia yang terbilang rendah. Hasil survei studi World's Most Literate Nations Rank 2016 menunjukkan Indonesia menempati urutan ke-60 dari 61 negara dalam minat baca (Webcapp.ccsu.edu, 2016). Inilah yang kemudian mendorong informan mengembangkan minat baca masyarakat dengan mendirikan komunitas menulis yang membawa konten dakwah. Untuk menulis, seseorang tentunya harus membekali dirinya dengan membaca.

Dalam webinar bertema "Paradigma Literasi Baca Tulis di Era Digital" yang diselenggarakan oleh Siberkreasi, Prof. Dr. Gufran Ismail, Guru Besar Antropolinguistik, menyampaikan bahwa di era digital saat ini, masyarakat menghadapi perubahan perilaku dalam baca tulis yaitu dari media cetak kertas menjadi media layar kaca dengan teknologi digital. Pada 
perubahan ini terjadi peralihan pengalaman dan pembelajaran kecerdasan kinestetik, yaitu adanya peluang memperoleh bacaan lebih banyak. Akan tetapi, perubahan pada pemakaian media ini justru menghadirkan suatu komunitas yaitu netizen yang rajin berinteraksi di media digital berupa komentar-komentar singkat lewat tulisan. Inilah yang disebut oleh Gufran sebagai bertutur dengan tulisan berupa komentar dan update status di media sosial. Perilaku ini ternyata tidak menjadikan minat membaca menjadi lebih tinggi. Dengan adanya fenomena ini, Kemdikbud menggagas ide menyediakan taman bacaan digital untuk mendorong masyarakat gemar membaca (Kemdikbud.go.id, 2021). Artinya, kebiasaan membaca harus difasilitasi, tidak bisa sekadar mengandalkan media yang ada namun tidak dikelola kontennya. Ini juga yang dimaksud oleh McLuhan bahwa media online adalah lingkungan yang membentuk budaya masyarakat bergantung kepada bagaimana media itu dikelola atau dibentuk (West \& Turner, 2018).

Aktivitas menulis bisa dikatakan cara intelektual dalam menyampaikan ide atau pesan. Selain mendapatkan ilmu, orang yang membaca juga diajarkan untuk berpikir runut dengan pola argumentasi dan pengungkapan fakta serta solusi yang diberikan. Inilah yang telah dicontohkan oleh Buya Hamka dalam dakwah beliau, yang menerapkan salah satu aktivitas dakwah yang berpengaruh bagi masyarakat di masa itu, yaitu dakwah bil qalam. Beliau adalah seorang ulama sekaligus wartawan, penulis, editor, dan penerbit. Tulisan-tulisan beliau mengandung nilai-nilai dakwah yang membangkitkan kesadaran dan memberikan pencerahan pada umat. Semasa hidupnya, Buya Hamka sudah menulis 118 judul yang terdiri dari buku, cerpen, dan artikel yang dimuat di berbagai media yang sebagian besar membawa unsur dakwah dan pemikiran Islam di dalamnya (Raihan, 2019).

Dalam beberapa penelitian juga disebutkan bahwa penyediaan konten-konten digital seperti perpustakaan digital berupa $e$-book, e-jurnal, dan sumber-sumber berupa tulisan digital lainnya akan memotivasi dan mendorong orang untuk membaca. Ini akan semakin baik lagi jika memanfaatkan berbagai platform yang ada di media online untuk mengakomodasi ketersediaan dan penyebaran konten tersebut (Fitriyanti \& Artikel, 2021; Kurniasih, 2016; Nurchaili, 2016; Saputri \& Khairani, 2021).

Apa yang dilakukan oleh Komunitas Revowriter adalah upaya untuk menyediakan kontenkonten digital dengan perspektif Islam. Saat ini, dengan kecanggihan teknologi, mencari konten dakwah Islam tidaklah hal yang sulit. Semua tersedia dalam berbagai platform. Dalam, penyampaian dakwahnya, Komunitas Revowriter tidak sekadar menyebarkan produk tulisan mereka, tetapi juga mengajak muslimah lainnya untuk ikut bersama-sama menyebarkan dakwah. Caranya cukup unik yaitu dengan membuat tantangan menulis.

Komunitas Revowriter mempromosikan dan memperkenalkan aktivitas komunitas mereka lewat tantangan menulis. Tantangan ini cukup menarik antusiasme berbagai kalangan muslimah. Tulisan boleh ditulis dengan tema bebas, belum spesifik mengulas tentang konten Islam. Namun, karena tantangan ini diikuti oleh sebagian besar anggota komunitas Revowriter, maka peserta lain ikut terwarnai menulis artikel dengan tema islami. Melalui tantangan ini mereka bergabung ke Komunitas Revowriter, kemudian ikut belajar menulis dan menyebarkan dakwah Islam. 
Anggota yang telah bergabung akan diarahkan untuk mengikuti Kelas Basic dan Intermediate. Dua kelas pelatihan menulis ini adalah bekal awal bagi penulis Revowriter. Setelah itu ada beberapa pelatihan lainnya yang bisa diikuti untuk menambah ilmu kepenulisan dan ilmu Islam dalam membangun konten dakwah yang berpengaruh.

Gambar 3. Poster Tantangan Menulis dari Revowriter

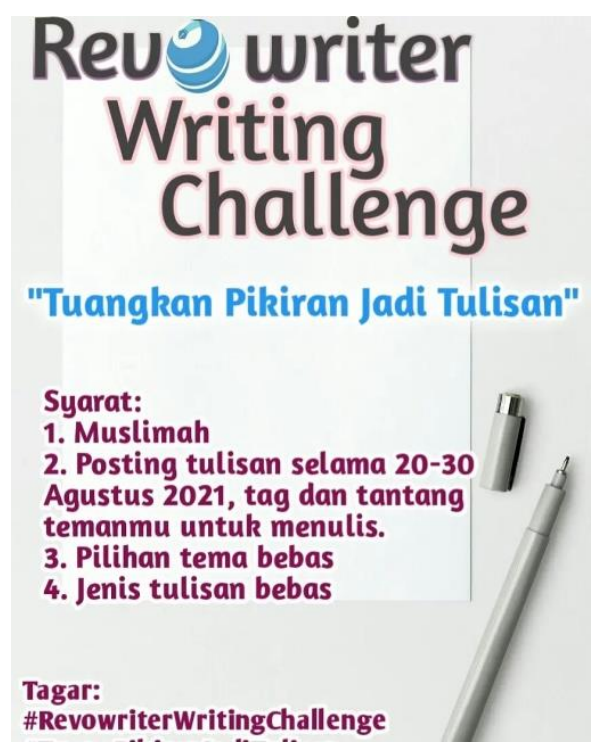

Sumber: Instagram @ revowriter

Cara Komunitas Revowriter mengembangkan wawasan dan ilmu mereka cukup menarik yaitu mengadakan program Bulan Baca Revowriter untuk anggotanya. Karena aktivitas mereka menulis, maka tuntutan untuk memperluas ilmu dan pengetahuan menjadi suatu keharusan. Aktivitas membaca dan membuat resensi buku ini diperuntukkan bagi semua anggota Revowriter. Tulisan resensi dapat mereka publikasikan di media sosial atau media online eksternal.

Komunitas ini telah menjadi wadah untuk meningkatkan minat baca di masyarakat. Dengan mengangkat isu kekinian pada tulisan mereka, semakin memperkaya spektrum pengetahuan dan bacaan mereka. Sebelum menulis mereka harus membekali diri dengan mencari bahan bacaan atau sumber-sumber yang bisa memperkaya ulasan tulisan mereka mulai dari fakta, pendapat para pakar atau opini yang berkembang di masyarakat, kemudian merujuk pada penggalian hukum para ulama dalam memandang persoalan tersebut. Hal ini berdampak pada tulisan yang mereka hasilkan. Temanya beragam, namun tetap memberikan sudut pandang dan solusi Islam terhadap fakta dan permasalahan yang diangkat. 
Gambar 4. Poster Bulan Baca Revowriter

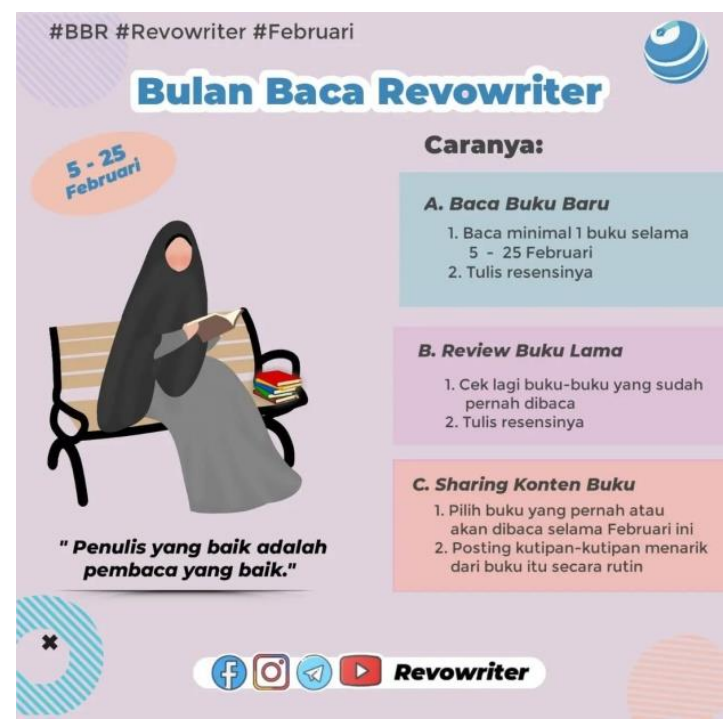

Sumber: Instragram @revowriter

Untuk mempertahankan ikatan komunitas mereka, maka pendiri komunitas ini bersama strukturnya menyelenggarakan berbagai agenda untuk membangkitkan semangat menulis dan untuk menjalin hubungan antar-anggotanya. Selama pandemi, banyak agenda yang mereka lakukan melalui pertemuan online seperti memperingati milad salah satu grup alumni Revowriter atau melakukan seminar dan talk show online yang membahas seputar kepenulisan. Selain itu juga mengundang penulis senior dari komunitas lain agar dapat berbagi pengalaman dan tips menulis. Menjalin hubungan dengan berbagai penulis dari komunitas lain yang memiliki tujuan mendakwahkan Islam semakin membangkitkan semangat untuk menulis. Adanya diskusi akan membuka inspirasi untuk berkreasi dalam menulis dan bagaimana membangun perspektif Islam dalam tiap tulisan.

\section{Dakwah bil Qalam dalam Platform Digital}

Komunitas Revowriter hingga saat ini sudah memiliki alumni sebanyak 1500 orang. Tiap alumni memiliki grup dan leader-nya masing-masing untuk mengelola dan mengarahkan aktivitas anggota satu angkatan. Hingga saat ini, aktivitas menulis terus mereka dilakukan kemudian mengirimkannya ke berbagai media online. Tulisan itu juga mereka bagikan ke masing-masing media sosial yang mereka punya. Karakter media baru ini yang mereka manfaatkan untuk menyebarkan konten secara masif ke berbagai platform media digital.

Menurut pendiri komunitas Revowriter, media online berbeda dengan media tradisional seperti koran dan buku, di mana tulisan pada media tradisional diproduksi terbatas. Untuk mendapatkannya harus melalui usaha tertentu, serta penyebarannya pun tidak luas. Ini berbeda sekali dengan media online yang sangat fleksibel. Maka dari itu, pilihan untuk mempublikasikan tulisan lewat media online adalah opsi yang tidak dapat dielakkan. Apa yang dilakukan oleh 
Komunitas Revowriter adalah bagaimana mengikuti tantangan zaman dengan memanfaatkan fasilitas yang memudahkan mereka dalam menyampaikan pesan dakwah. Akan sangat rugi jika melewatkan kecanggihan teknologi dalam menyebarkan dakwah Islam. Semua orang berlombalomba untuk membuat konten di media online, maka untuk tujuan kebaikan seharusnya kita lebih bersemangat, begitu penjelasan informan yang diwawancari. Media online memiliki banyak keunggulan dengan karakter multimedia yang dimilikinya. Apalagi sekarang semua itu bisa disimpan dan diakses dalam satu perangkat saja berupa smartphone. Banyak pihak yang telah diuntungkan dengan adanya integrasi media komunikasi lewat media digital (Sule \& Sulaiman, 2021).

Perkembangan media baru internet saat ini sangat cepat dan memberikan banyak pilihan platform. Pada awalnya, internet hanya berupa website yang berfokus memberikan informasi kepada masyarakat. Sifatnya masih seperti media tradisional dengan arah informasi searah, hanya saja tampilan sudah digital. Konsep "digital" ini salah satunya yang dimaknai sebagai hal yang baru pada new media (McQuail, 2010). Setelah periode awal, internet berkembang dengan inovasi yang membawa platform media sosial. Para pakar menyebut kondisi ini teknologi yang mengalami peralihan dari budaya "read/only", di mana pengguna hanya bisa membaca konten, menuju budaya "read/write". Jenis media sosial sangat beragam bergantung pada tujuan pemakaiannya dan jenis konten yang bisa ditampilkan, seperti Facebook, Yotube, Instagram, dll. Karakter media sosial bersifat interaktif yang memungkinkan terjadinya komunikasi dua arah secara langsung antara penyedia konten dan audiens atau antar-audiens itu sendiri (Campbell et al., 2016; McQuail, 2010).

Komunitas Revowriter telah masuk ke budaya read/write di mana sebagai pengguna media online mereka mencari bahan untuk konten, membuat konten, dan menyebarluaskannya. Jika pada media tradisional penguna media hanya bisa membaca saja maka di masa sekarang, pengguna adalah pihak yang aktif dalam memproduksi konten. Konten ini basisnya adalah tulisan (script) yang kemudian dapat dikonversikan ke berbagai platform digital lainnya apakah video atau audio. Bisa juga menghasilkan tulisan lain yang sudah diolah di dalam ruang-ruang diskusi di media sosial.

Jika merujuk kepada makna dakwah yang berarti menyeru, mengajak memanggil, atau menghimbau (Ahmad, 2014; Raihan, 2019). Maka, seruan dakwah yang dilakukan oleh Komunitas Revowriter dapat dikatakan sebagai konten informasi yang mengandung pesan yang dapat menggerakkan dan mengubah padangan masyarakat ke arah pandangan Islam. Kebebasan dalam membuat konten dan menyebarluaskannya akan membangun pemikiran khalayak, bahkan dapat memobilisi masyarakat melakukan perubahan sosial (Gil de Zúñiga \& Chen, 2019). Karakter media yang bebas seperti ini dimanfaatkan dalam penyebaran konten dakwah. Pada media digital, orang bisa memilih untuk membuat platformnya sendiri dan mengarahkan kontennya yang mengandung nilai-nilai tertentu untuk disebarluaskan (Straubhaar et al., 2012). Akan tetapi, di sini, Komunitas Revowriter tidak hanya menyebarkan tulisan mereka melalui website komunitas, akun komunitas di berbagai media sosial, serta akun peribadi dari para penulisnya, tetapi juga menyebarkannya ke website eksternal. Pengelolaannya menganut konsep 
media organisasi yang memiliki agenda setting dan pembingkaian informasi tersendiri. Tujuannya menyebarkan opini ke media eksternal adalah agar konten mereka dapat tersebar ke media yang memiliki pengaruh lebih luas.

Dengan fitur share di media sosial yang dapat menyebarkan berita secara luas melalui lingakaran perteman, Komunitas Revowriter memanfaatkan kemudahan itu dalam menyebarkan tulisan mereka. Nantinya, tulisan-tulisan ini akan diperbincangkan dan dipertukarkan dalam forum-forum diskusi. Pengikut mereka pun banyak yang berinisiatif membagi tulisan tersebut tanpa diminta karena dianggap bermanfaat. Inilah keunggulan media sosial yang sangat memudahkan penyebaran dakwah Islam. Sesuai dengan definisi dan fungsinya, teknologi adalah alat yang digunakan manusia untuk memudahkan urusan manusia. Semua bergantung pada manusianya apakah akan digunakan untuk kebaikan atau keburukan (Sule \& Sulaiman, 2021).

Media online sangat efektif dan efisien digunakan karena mudah diakses oleh siapa saja, biayanya terjangkau, penyebaran informasi bisa sangat cepat dan dapat disebarluaskan lagi melalui platform digital yang beragam (Campbell et al., 2016). Apalagi saat ini media internet sudah menjadi kebutuhan bagi setiap orang dengan berbagai tujuan. Sebagaimana yang dikatakan McLuhan bahwa media sudah menjadi lingkungan (environment) bagi penggunanya (Littlejohn \& Foss, 2009; West \& Turner, 2018). Mereka hidup di sana, bergantung kepada media dalam berbagai urusan, tak terkecuali dalam mendapatan informasi dan ilmu. Informan memandang, dengan adanya media internet telah semakin memudahkan urusan dakwah baik dari cara penyebarannya maupun dalam hal mengemas pesan kepada obyek dakwah.

Membahas kembali tentang dakwah bil qalam, Ibu Asri Supatmiati mengatakan bahwa pemilihan dakwah melalui tulisan tidaklah mengurangi penyebaran nilai-nilai dakwah tersebut, sebagaimana yang telah dijelaskan di atas bahwa di era digital sekarang platform media bisa dipilih dan dikemas sesuai kebutuhan dan tujuan. Beliau menilai bahwa dalam media online semua konten dirumuskan dan dibuat konsepnya melalui tulisan, seperti yang dibahas oleh Campbell tentang budaya read/write (Campbell et al., 2016). Tulisan adalah dasar dalam mengembangkan ide. Dari tulisan inilah kemudian dikonversikan ke berbagai bentuk platform apakah audio podcast, narasi video, bahkan keterangan (caption) foto/gambar dan video masih membutuhkan deskripsi tulisan yang disediakan oleh media sosial untuk menjelaskan konten yang diunggah. Untuk itu, dakwah dengan basis tulisan justru membawa banyak keuntungan sebagai fondasi mengonsep konten media.

Dalam wawancara, Ibu Asri mengungkapkan bahwa komunitas ini mengusung nama "Revowriter" merupakan singkatan dari revolutioner writer yaitu penulis yang revolusioner. Maknanya di sini adalah beliau merevolusi makna menulis itu tidak selalu harus menjadi penulis yang menghasilkan banyak buku atau menjadi penulis terkenal dll. Seharusnya makna menulis ditujukan kepada bagaimana kita bisa menyebarkan tulisan ke berbagai media untuk memberikan kebaikan kepada orang lain.

Anggota komunitas ini tidak hanya berfokus kepada aktivitas menulis tetapi juga mengembangkan bakat anggotanya yang memiliki kemampuan dalam membuat konten dengan jenis video, tayangan, atau desain. Ini karena platform media sosial yang ada menyediakan 
banyak sarana yang seharusnya dapat dimanfaatkan dengan baik. Semua itu tidak akan ada maknanya jika tidak ada kontennya atau script tulisannya. Artinya tulisan adalah dasar dari membuat konten. Maka dari itu, komunitas ini melatih anggotanya untuk dapat menggali ide dan pemikiran lewat tulisan yang nanti bisa dikembangkan ke berbagai platform lainnya. Ibu Asri berharap anggota Revowriter dapat mentransformasikan tulisan mereka ke dalam berbagai bentuk media digital yang ada, yang mampu menjangkau kalangan milenial atau generasi setelahnya, termasuk menjangkau muslimah dengan latar belakang ibu rumah tangga, atau netizen secara umum. Anggota Revowriter yang suka membaca akan diberikan artikel tulisan, yang suka mendesain akan diarahkan membuat desain, yang suka membuat video bisa merambah aktif membuat video di kanal Youtube. Ini dilakukan agar tulisan-tulisan mereka dapat ditransformasikan ke dalam bentuk visual yang menarik karena masyarakat memiliki minat dan segmen yang berbeda-beda.

Dalam penelitian ini, dakwah bil qalam yang dilakukan oleh Komunitas Revowriter adalah bagian dari cara dakwah Islam yang memanfaatkan media teknologi komunikasi yaitu internet sebagai wadah penyebaran konten dakwah. Penggunaan media online saat ini sudah berupa kebutuhan bagi masyarakat untuk menggunakannya. Konten Revowriter tak hanya masuk ke platform media formal tetapi juga masuk ke ruang aplikasi komunikasi semacam Whatsapp dan Telegram. Terbukti apa yang dikatakan oleh McLuhan bahwa media is the message atau media adalah pesan itu sendiri. Pemilihan media yang efektif akan menjadikan konten yang dibawa akan tersebar dengan baik. Tiap platform memiliki kekhasannya sendiri sehingga konten harus dikemas semenarik mungkin atau sesuai segmennya.

Dalam Teori Medium atau Ekologi Media disebutkan bahwa media melingkupi setiap tindakan di dalam masyarakat. Ini artinya media adalah sesuatu yang tidak bisa dilepaskan dari kehidupan manusia, terlebih lagi manusia modern yang kehidupannya sudah sangat bergantung ke media komunikasi canggih (West \&Turner, 2018). Komunitas Revowriter yang memanfaatkan media digital untuk menyebarluaskan konten dakwah yang mereka buat telah masuk ke ruang-ruang komunikasi yang digunakan oleh masyrakat secara umum. Kebutuhan masyarakat akan ilmu Islam telah diakomodasi oleh media digital dan tersedianya konten dakwah yang mereka sajikan.

Komunitas Revowriter berusaha memperbaiki persepsi masyarakat dengan memberikan pemahaman berupa solusi bagi kehidupan masyarakat yang belum memahami hukum Islam dari suatu perkara. Konten dakwah bil qalam telah membantu mengubah sudut pandang masyarakat yang awalnya keliru menjadi lurus dengan mengangkat kasus-kasus yang terjadi di masyarakat kemudian menjelaskannya dalam bingkai perspektif Islam. Ini artinya tulisan yang disampaikan oleh komunitas Revowriter telah membawa perubahan di masyarakat dengan menjadikan pandangan mereka mengikuti ajaran Islam, serta memotivasi banyak kalangan ikut bersama menyebarkan dakwah Islam lewat komunitas menulis yang mereka jalankan.

\section{Konten Dakwah Komunitas Revowriter}

Jenis tulisan yang dibuat oleh penulis Revowriter adalah tulisan artikel opini panjang dan pendek. Tulisan yang dibuat tidak selalu tulisan berat, tetapi juga berupa tulisan ringan seperti 
kutipan-kutipan ayat dan hadits, Selain itu, juga ada yang menulis tulisan nonfiksi, namun lebih dititikberatkan pada penulisan opini tentang peristiwa terkini yang kemudian dibedah dan dianalisis menurut sudut padang Islam. Targetnya agar bisa menyampaikan bagaimana perspektif Islam kepada audiens ketika dihadapkan pada isu atau permasalahan yang sedang terjadi. Berikut ini contoh tulisan anggota Revowriter yang sudah dipublikasikan di media online.

Gambar. 5 Hasil karya anggota Komunitas Revowriter

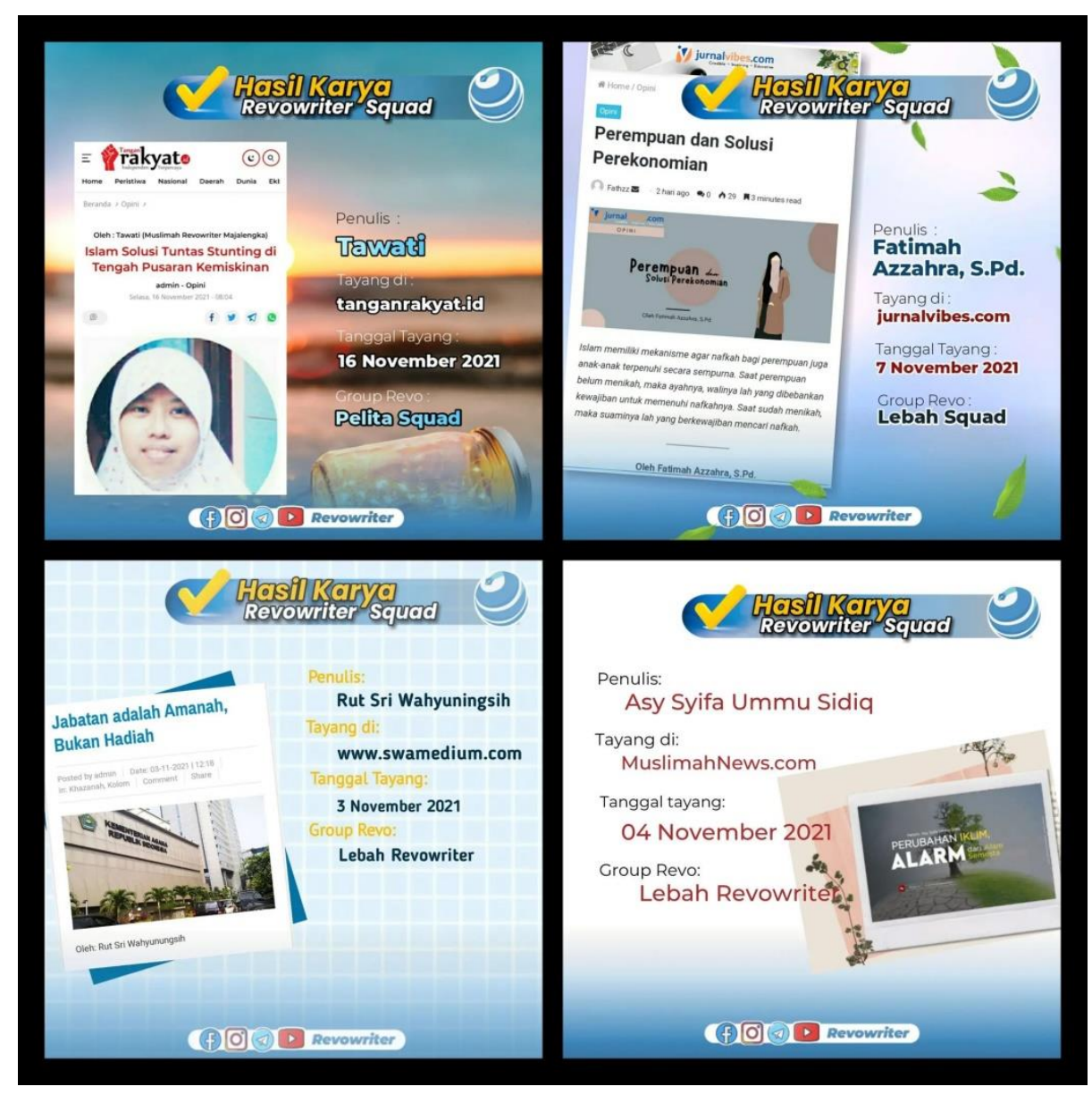

Sumber: Instagram @ revowriter

Teknik menulis konten dakwah berupa artikel opini dianggap informan lebih efektif karena dengan memaparkan fakta kemudian membuat analisis dan solusi menurut pandangan Islam lebih cepat dipahami oleh masyarakat dalam memahami ajaran Islam. Menulis konten nonfiksi terkadang membutuhkan waktu lama sehingga karya yang dihasilkan akan lama pula dipublikasikan. Apalagi pesan yang disampaikan terbatas dalam tulisan fiksi. Ini juga karena karakter media online yang sangat cepat berganti isu sehingga harus cepat juga merespons dan menyajikannya dalam bentuk tulisan. Menulis artikel opini lebih mudah formulanya dibanding menulis fiksi karena bisa langsung ditulis dalam jangka waktu yang singkat. Informan mengibaratkan tulisan opini seperti makanan cepat saji yang pengolahannya tidak memakan 
waktu lama, jadi bisa langsung dinikmati. Selain tulisan opini, Komunitas Revowriter juga menghasilkan karya berupa tulisan story telling atau features, meme, dan kutipan singkat. Untuk konten fiksi, Revowriter membuat kategori khusus yang diberi nama Jurnal Fiksi sebagai wadah bagi anggotanya yang memiliki ketertarikan pada tulisan fiksi dakwah.

Konten dakwah yang dibawa oleh Komunitas Revowriter dalam tulisan mereka adalah konten Islam kaffah. Informan menjelaskan alasan menjadikan Islam kaffah sebagai konten karena sumber inspirasi yang tidak akan pernah habis adalah dari Al-Qur'an dan Sunnah. Dari sana bisa digali berbagai jenis inspirasi di mana berbagai aspek bisa dibedah dalam sudut pandang Islam seperti aspek politik, ekonomi, sosial, pendidikan, dan kesehatan. Semua itu disampaikan dengan harapan masyarakat memiliki pandangan yang komprehensif tentang Islam, sehingga masyarakat tidak hanya memandang Islam sekadar agama ritual tetapi juga memiliki konsep-konsep yang sempurna dan totalitas terkait berbagai permasalahan yang ada. Jadi dalam konten Islam kaffah, konsep akidah dan syariah keduanya dibahas. Dengan konten Islam seperti ini, maka penulis tidak akan kehabisan ide dalam menyampaikan konsep dakwah Islam.

Konsep Islam Kaffah dalam ulasan penelitian Riana Ratna Sari menjelaskan bahwa Islam mengatur seluruh kegiatan di dunia. Dalam al-Qur'an surah al-Baqarah ayat 208, Ibnu Katsir menafsirkan ayat ini bahwa Allah memerintahkan kepada hamba-hamba-Nya yang beriman kepada-Nya dan membenarkan Rasul-Nya, agar berpegang seluruhnya kepada tali Islam dan syari'at-Nya, mengerjakan perintah-Nya, serta menjauhi semua larangan-Nya sekuat tenaga. Islam kaffah berarti mentaati ajaran Islam secara menyeluruh, tidak memilih aturan yang disukai saja dan meninggalkan yang tidak disukai karena pada dasarnya Islam kaffah adalah Islam melingkupi dan mengatur semua aspek kehidupan manusia. Intinya, Islam kaffah terdiri atas iman (akidah) dan aturan kehidupan (syariah) (Ratna Sari, 2019).

Untuk teknik penulisan, Komunitas Revowriter menerapkan teknik yang sama pada semua penulisnya walaupun latar belakang mereka berbeda-beda. Kreativitas akan muncul dengan sendirinya ketika seseorang mulai terbiasa menulis atau seberapa lama mereka menekuni dunia tulis-menulis. Untuk tahap awal, anggota Revowriter diberikan formula menulis atau rumusan baku berupa dasar penulisan artikel standar yaitu penjabaran tentang fakta, analisis terhadap fakta, kemudian solusi menurut pandangan Islam. Dengan formula seperti ini, penulis bisa mengembangkan tulisannya dari berbagai sisi (angle). Tinggal mengasah kreativitas penulis dalam meramu tulisan. Jadi walaupun persoalan yang diangkat sama, bisa jadi cara mengulasnya akan berbeda dari tiap penulis. Formula seperti ini diterapkan untuk memudahkan para penulis, karena menulis opini berarti berbicara tentang kecepatan menulis dan menyebarkannya di media. Semakin cepat penulisan sebuah tulisan, maka isu juga akan cepat diulas. Ini mengingat isu yang beredar di masyarakat sangat cepat bergulir dan berganti. Bagaimanapun, karakter dan teknik penulisan jurnalistik memang tidak bisa dilepaskan dari tulisan yang dibuat oleh Komunitas Revowriter. 


\section{Simpulan}

Komunitas Revowriter adalah komunitas menulis yang berfokus pada penulisan artikel opini. Dakwah bil qalam diambil sebagai cara dakwah untuk meningkatkan minat baca atau literasi umat yang kian menurun. Dengan teknik rekrutmen yang menarik, komunitas ini bisa mengajak banyak orang untuk bergerak menulis konten dakwah untuk sama-sama menyebarkan kebaikan. Komunitas ini membawa konten Islam kaffah agar permasalahan umat dapat mereka ulas dan sampaikan dalam perspektif Islam secara utuh. Konsep kaffah itu sendiri adalah menyeluruh yang artinya Islam mengurusi, memiliki solusi, dan sudut pandang untuk semua aspek kehidupan manusia. Anggota komunitas menjadikan isu terkini sebagai kajian dan analisis tulisan mereka sehingga umat dapat memahami permasalahan dalam sudut padang Islam. Keberadaan internet yang menyediakan berbagai platform menginisiasi komunitas ini untuk menyebarkan tulisan mereka ke berbagai media online. Semua tulisan disebarkan di akun pribadi media sosial mereka dan akun eksternal yang dapat diakses oleh banyak pihak. Komunitas ini memanfaatkan jaringan tanpa batas serta kemampuan media digital untuk membagi konten ke dalam berbagai platform yang disebut dengan konvergensi media. Selain itu, karakter media digital yang mampu menyimpan atau mengarsipkan data memudahkan orang dalam pencarian tulisan mereka di berbagai media online.

\section{Referensi}

Abdullah, M. Q. (2019). Pengantar Ilmu Dakwah. Qiara Media.

Adeni, A., \& Hasanah, S. (2020). Kontribusi Dakwah Bil Qalam Syaikh Nawawi Al-Bantani terhadap Nasionalisme Pesantren. Komunika: Jurnal Dakwah Dan Komunikasi, 14(1), 139154. https://doi.org/10.24090/komunika.v14i1.3597

Ahmad, N. (2014). Tantangan Dakwah di Era Teknologi dan Informasi. Addin: Media Dialektika Ilmu Islam, 8(2), 319-344. https://doi.org/http://dx.doi.org/10.21043/addin.v8i2.600

Al-Haddad, A. bin A. (2018). Dakwah Cara Nabi Jilid II. Cahaya Ilmu Publisher.

Al-Madkhali, R. bin H. (2006). Fiqih Dakwah Para Nabi 'Alaihimus salam. Media Tarbiyah.

Al Isra, A. (2019). Da'wah bil Qalam: From Political Islam to the "Islamic Way" of Resistance through Writings in Indonesia. Jurnal Emik, 2(2), 149-159. https://ejournals.umma.ac.id/index.php/emik/article/view/339

Ali, M., Budyastomo, A. W., \& Harun, M. H. (2021). The Impact Of Social Media For The Development Of Da'wah In Indonesia. Religia: Jurnal Ilmu-Ilmu Keislaman, 24(1), 22-33. https://doi.org/10.28918/religia.v24i1.2224

Briandana, R., Doktoralina, C. M., Hassan, S. A., \& Hasan, W. N. W. (2020). Da'wah communication and social media: The interpretation of millennials in southeast Asia. International Journal of Economics and Business Administration, 8(1), 216-226. https://doi.org/10.35808/ijeba/543

Campbell, R., Martin, C. R., \& Fabos, B. (2016). Media \& Culture: Mass Communication in Digital Age (Tenth Edit). Bedford/St.Martin's.

Creswell, J. W. (2014). Research design: Qualitative, Quantitative, and Mixed Methods Approaches (Fourth). Sage Publications.

Creswell, J. W., \& Poth, C. N. (2016). Qualitative Inquiry \& Research Design: Choosing Among 5 Approaches. In Sage Publication (Fourth Edi). Sage Publications. 
Denzin, N. K., \& Lincoln, Y. S. (2018). The Sage Handbook of Qualitative Research (N. K. Denzin \& Y. S. Lincoln (Eds.); Fifth). Sage Publications. https://doi.org/10.1007/s11229017-1319-x

Fitria, R., \& Aditia, R. (2019). Prospek dan Tantangan Dakwah Bil Qalam sebagai Metode Komunikasi Dakwah. Jurnal Ilmiah Syi'ar, 224. https://doi.org/10.29300/syr.v19i2.2551

Fitriyanti, P., \& Artikel, I. (2021). Penggunaan E-Book Untuk Meningkatkan Minat Baca. 11, 170-177. http://jurnal.umk.ac.id/index.php/RE

Gil de Zúñiga, H., \& Chen, H. T. (2019). Digital Media and Politics: Effects of the Great Information and Communication Divides. Journal of Broadcasting and Electronic Media, 63(3), 365-373. https://doi.org/10.1080/08838151.2019.1662019

Jalaludin, J., Ghulan, Z., \& Ghofur, A. (2021). Analisis Wacana Strategi Dakwah Sultan Agung Adi Prabu Hanyokrokusumo Jalaludin. Dakwatuna, 7(1), 12-26.

Kemdikbud.go.id. (2021). Paradigma Literasi Baca Tulis di Era Digital. Kemdikbud.Go.Id. http://ditpsd.kemdikbud.go.id/artikel/detail/minat-baca-tulis-netizen-turun-di-era-digitallebih-banyak-komen-dan-update-status

Kurniasih, N. (2016). Reading Habit in Digital Era: Indonesian People do not Like Reading, is it True? World Culture Forum, 41, 1-4.

Latepo, I., Suharto, S., \& Nurdin, N. (2021). Understanding Muslim Preaching Students' Use of Social Media. International Journal of International Relations, Media and Mass Communication Studies, 7(1), 52-66.

Littlejohn, S. W., \& Foss, K. A. (2009). Encyclopedia of Communication Theory (S. W. Littlejohn \& K. A. Foss (Eds.)). Sage Publications.

Masyhur, M. (2014). Jalan dakwah. Konsis Media.

McQuail, D. (2010). McQuail 's Mass Communication Theory (Sixth Edit). Sage Publications. http://docshare04.docshare.tips/files/28943/289430369.pdf

Miles, M. B., \& Huberman, A. M. (2014). Qualitative Data Analysis: A Methods Sourcebook. Sage Publications.

Mupida, S., \& Shalihati, K. N. (2019). Dakwah By the Pen: Salim a. Fillah'S Authority in Pro U Media. INJECT (Interdisciplinary Journal of Communication), 4(1), 27. https://doi.org/10.18326/inject.v4i1.27-46

Nurchaili. (2016). Menumbuhkan Budaya Literasi Melalui Buku Digital. Libria, 8(2), 197-209. https://doi.org/http://dx.doi.org/10.22373/1211

Omar, F. I., Hassan, N. A., \& Sallehuddin, I. S. (2015). Islamic perspectives relating to business, arts, culture and communication. Islamic Perspectives Relating to Business, Arts, Culture and Communication, 43-55. https://doi.org/10.1007/978-981-287-429-0

Patton, M. Q. (2015). Qualitative Research \& Evaluation Methods: Integrating Theory and Practice (Fourth). Sage Publications.

Raihan. (2019). Dakwah Menurut Perspektif Buya Hamka. Al-Idarah: Manajemen Dan Administrasi Islam, 3(1), 95-108. https://doi.org/http://dx.doi.org/10.22373/alidarah.v3i1.4803

Ratna Sari, R. (2019). Islam Kaffah Menurut Pandangan Ibnu Katsir. Ishlah: Jurnal Ilmu Ushuluddin, Adab Dan Dakwah, 1(2), 132-151. https://doi.org/10.32939/ishlah.v1i2.46

Saputri, E., \& Khairani, S. (2021). Peran Pemerintah dalam Meningkatkan Minat Baca melaui Pojok Baca Digital ( POCADI ) di Kota Lhokseumawe, Aceh. JIPKA: Jurnal Informasi, Perpusatakaan, Dan Kearsipan, 1(1), 27-39. 
Straubhaar, J., LaRose, R., \& Davenport, L. (2012). Media Now_Understanding Media, Culture, and Technology(2011)-1. Wadsworth Cengange Learning.

Sule, M. M., \& Sulaiman, Y. (2021). Enhancing Da'wah and Spread of Knowledge Via Social Media Platforms. Jurnal Ilmiah Peuradeun: The International Journal of Social Science, 9(1), 145-160. https://doi.org/10.26811/peuradeun.v9i1.549

Webcapp.ccsu.edu. (2016). World's Most Literate Nations Ranked. https://webcapp.ccsu.edu/?news=1767\&data

West, R. L., \& Turner, L. H. (2018). Introducing Communication Theory: Analysis and Application (Sixth Edit). McGraw-Hill Education. 